College of Education, Qatar University

*Email: michaelhr@qu.edu.qa

1 Professor of Educational Leadership and the coordinator of the MEd. in Educational Leadership Program at Qatar University. His research interests educational reform, curriculum, and the development of critical thought.

2 Lecturer at Qatar University, her research interests educational reform/ language planning and policy.
DOI: $10.5339 /$ nmejre.2011.1

Published: 16 May 2011 (C) 2011 Romanowski \& Alkhateeb, licensee Bloomsbury Qatar Foundation Journals. This is an open access article distributed under the terms of the Creative Commons Attribution License CC BY 3.0 which permits unrestricted use, distribution and reproduction in any medium, provided the original work is properly cited.

\section{Truth against truth: American and Arab history school textbooks portrayal of the Arab-Israeli conflict}

Michael H. Romanowski*1 and Hadeel Alkhateeb ${ }^{2}$

\section{ABSTRACT}

Textbooks reflect a national consensus regarding the knowledge, values and perspectives that a society wants conveyed to their students. Through textbooks, students are exposed to a dominant narrative that presents an official story that shapes contemporary patriotism (Hein and Selden, 2000). This paper centers on how the narratives of textbooks portray the Arab-Israeli conflict and other relevant events. Textbooks from Iraq, Jordan, Egypt and the United States are examined to determine what knowledge is transmitted to students about the Arab-Israeli conflict. Findings indicate that the conflict is oversimplified, important information is omitted and textbooks provide limited narratives of the conflict. The authors of this study suggest the implementation of a narrative-based approach to teaching history so that students are provided with opportunities to develop a critical analysis of textbook knowledge and to discover that historical events are composed of multiple narratives that should be examined.

Keywords: textbooks, content analysis, qualitative research 


\section{INTRODUCTION}

Textbooks are often considered value-free educational tools that innocently provide students with needed knowledge and skills. However, textbooks are not neutral transmitters of knowledge. Critical theorists have long argued that textbooks not only provide a generation of citizens with a sanctioned version of their historical past, but also that this version is a highly politicized, ideological device that shapes students' views and understanding of the world (Cherryholmes et al., 2005; Giroux, 1988; Anyon, 1979). Apple and Christian-Smith (1991) point out that textbooks are important artifacts of culture. They create what society has recognized as legitimate knowledge by signifying particular constructions of reality that members of society want transmitted to their children. School textbooks have an important social function, "to represent to each generation a sanctioned version of human knowledge and culture" (De Castell and Luke, 1989, p. vii).

Regarding the knowledge found on textbook pages, McLaren (1998) argues, "knowledge acquired in school or anywhere for that matter is never neutral or objective but is ordered and structured in particular ways" (p. 169) and embodies particular interests, assumptions and beliefs. Although it is impossible to do otherwise, history textbooks promote a particular biased understanding of history but yet are still perceived as objective, truthful and factual educational tools. Even textbooks that adopt a 'fact stating' format still send powerful messages to students because textbooks are written from a particular perspective. Hence, history textbooks should be consider "important artifacts of culture because they reflect a national consensus regarding the dominant cultural knowledge and values that members of society want transmitted to their children" (Romanowski, 2009, p. 27).

More importantly, the knowledge that is excluded from textbook pages could be just as, or even more important, than what is presented to students. Eisner (1994) argues the knowledge schools do not teach may be as important as what they do teach because "ignorance is not simply a neutral void; it has important effects on the kinds of options one is able to consider, the alternatives that one can examine, and the perspectives from which one can view a situation or problems" (p. 97). Adwan et al. (2002) point out that students often learn only one side of the story and usually it is their own perspective that is considered the 'right' one. Textbooks justify one side and offer a negative portrayal of the other, in a sense "one side's hero is the other side's monster" (Adwan et al., 2002, p. i). Students are neither taught about the bias nor do they learn others' historical narratives.

There is little doubt that one of the most controversial and ongoing conflicts in the world is the Arab-Israeli conflict. In what follows, we examine how textbooks from the United States, Jordan, Egypt and Iraq portray the Arab-Israeli conflict by describing findings from a content analysis. Our purpose is not only to discuss the knowledge included in textbooks but also important knowledge excluded in the description of these historical events. By examining the knowledge excluded, we illustrate how students' thinking is confined to the limited knowledge presented in these textbooks. Based on these findings, we suggest teachers utilize a narrative approach to teaching history that provides students with opportunities to develop empathy and understanding for the other's understanding of history.

\section{Examinations of American and Arab textbooks}

Any examination of American and Arab textbooks would reveal slanted versions of history. Wingfield and Karaman (1995) argue that "American textbooks are often Eurocentric, while Arab points of view regarding such issues as the Arab-Israeli conflict are presented inadequately or not at all". Barlow (1994) points out that some American textbooks often link Islam to violence and intolerance while omitting the commonalities with Christianity and Judaism. At times, textbooks discuss Allah as if the word referred to an Alien God remote from Judeo-Christian tradition.

The Middle East Studies Association and the Middle East Outreach Council have analyzed history and geography textbooks, finding "an over-portrayal of deserts, camels and nomads" in the chapter on the Middle East. The study concluded that the textbooks' portrayal of "Islam is so problematic that it is perhaps time for educators at the college and university level to send a red alert ...crude errors and distortions bound" (Barlow, 1994, p. vii).

Bard (1993) examined eleven world and seven American history texts that are among the most widely used and it was evident that inadequate and inaccurate depictions of Middle East history are the norm. He found that the textbooks suffered from oversimplification and distortions. For example, much of the crucial history of Palestine before 1948 is omitted and coverage of the Arab-Israeli conflict and the discussion of the causes and conduct of the Arab-Israeli wars are poor. The history of the Palestinians is full of factual errors, omissions and distortions and the textbooks' treatment of the peace process is consistently simplistic. 
American Textbook Council (2003) conducted a comprehensive review of world history textbooks. They found that during the last decade world history textbooks have expanded their coverage of non-Western civilizations that results in a more detailed look at Muslims through the centuries. Although not all textbooks content is misinformative, there are many explanations that remain puzzling. One concern is that history textbooks often provide simplistic and sloppy definitions and descriptions that fail to adequately explain important terms (Romanowski, 2009). For example, according to American Textbook Council (2003) terms like jihad and Shari'a are defined in a variety of ways and often times "explanations are almost meaningless chatter". Regarding controversial subjects, "world history textbooks make an effort to circumvent unsavory facts that might cast Islam past or present in anything but a positive light. Islamic achievements are reported with robust enthusiasm. When any dark side surfaces, textbooks run and hide".

An important yet often overlooked aspect of history textbooks is the description of their own narrative and the narratives of the other. For example Bar-Tal (2001) reports that Israeli high school textbooks stereotyped the Arabs negatively and that over the years, Israeli Jews were taught a negative and often delegitimizing view of Arabs; such as the Arabs as the enemy. He found that there are two major themes regarding Arab characteristics. The first deals with "their primitiveness, inferiority in comparison to Jews, backwardness and ignorance. The other theme relates to their violence, to characteristics like brutality, untrustworthiness, cruelty, fanaticism, treacherousness and aggressiveness". Bar-Tal suggests that the negative stereotyping is not at all surprising since the

"Jewish perception is founded on violent experiences with Arabs, adherence to their own Zionist goals, the insistence on relating only their own narrative, the concentration exclusively on their own challenges and needs, the focusing on Jews as victims, a lack of sensitivity and empathy to the aspirations of others, and the overall negation of the Arab case - all lead to the negative presentation of Arabs as such".

This stereotyping and negative portrayal of the other is not limited to Israeli textbooks but Arab textbooks also present similar portrayals of the other. Moughrabi (2001) argues that bias against Israel can been found in Arab textbooks. He states that since 1994, Palestinian children have been learning from their schoolbooks to identify Israel as the evil colonialist enemy who stole their land. These textbooks delegitimize Israel, do not instruct students "to see Israel as a neighbor with whom peaceful relations are expected. They do not teach acceptance of Israel's existence on the national level, nor do they impart tolerance of individual Jews on the personal level" (p. 7). It is vital that educators examine textbooks to sift out the messages that are transmitted to students and determine how to best address the content. With that in mind, several research questions were developed. These are as follows:

1. How do textbooks define important terms?

2. How are the specific Arab-Israeli conflicts described?

3. How are the UN resolutions presented?

4. How are US-Israeli relations described?

5. What are the implicit messages transmitted to students?

6. What knowledge is omitted that might shape students' understandings of historical events?

\section{METHODOLOGY}

Content analysis is best defined as a systematic, replicable technique for condensing words of text into categories based on explicit rules of coding (Weber, 1990). This research method is very useful when examining textbooks because the method "uses a set of procedures to make valid inferences from text" (Weber, 1990, p. 3). The process involves inductive reasoning that produces themes and categories that emerge from the text under the researchers' careful examination and comparison.

Prior to the analysis, a significant amount of time was spent reading, researching and discussing the details of the Arab-Israeli conflict in order to increase the prior knowledge of the researchers. The analysis began with a preliminary reading of each textbook recording the page numbers for all references to the Arab-Israeli conflict and other relevant events.

All relevant passages were carefully analyzed considering the above research questions. The analysis paid close attention to the presence or absence of words, images, messages and implicit or underlying meanings. All relevant passages in Arab textbooks were translated into English. Passages were coded as categories emerged. It is important to note that these passages have been adjusted to improve readability and any change does not alter the content or meaning. 


\section{Personal narratives}

The qualitative research paradigm suggests that the researcher is a vital part of the research process and because there is no objective point of view, it is impossible for the researcher to disconnect him or herself from the topic or people he or she is studying. The essence of the research is the interaction between the researchers and researched because this is where the knowledge is uniquely created. The key is that researchers have different narratives and the challenge is to demonstrate how these narratives are not a limitation but rather an asset to the research. An American and Palestinian narrative informs this research and as we engaged in the analysis and interpretation of the text, we realized that our own narratives and the interaction with the text and one another other shape our view of the Israeli-Arab conflict. At times our stories conflict, agree or mesh together to modify our existing understandings. More important, the interaction allows for a much more balanced analysis, a richer interpretation and multiple narrative examination of the textbooks' portrayal of the Arab-Israeli conflict.

\section{Sample}

The selection of the textbooks from Jordan, Iraq, and Egypt is based on information from colleagues who have extensive experience in Middle East education and teachers working in these particular education systems. We are convinced that these are the only textbooks used in their educational systems for secondary schools. Considering the monopolism of knowledge that Arab governments practice in their educational systems, we would argue it is safe to infer that additional Arab textbooks would render similar findings. The six American textbooks were selected based on the American Textbook Council's (ATC) list of widely adopted history textbooks. ${ }^{3}$ ACT identifies the nation's most widely adopted United States history textbooks used in public secondary schools and these combined hold an estimated 80 percent of the national market.

\section{Limitations}

As with any study, there are limitations to this investigation that should be considered. The major criticism of any content analysis is the acceptance of research based on the examination of textbooks removed from the context of their use. We cannot assume that the knowledge in these textbooks is either taught by teachers or learned by students. Secondly, all teachers mediate and transform text material when they employ it in the classroom and students bring their own biographies shaped by race, class, gender and reflected parental values that are used to selectively accept, interpret and reject knowledge taught in schools. Thirdly, history textbooks are not identical in their scope and sequence and both space constraints and political pressures differ. The examination of one historical event might do disservice to a particular textbook because the publisher might have given more detailed accounts of other episodes in history. Finally, there are always concerns regarding the translation of Arabic into English. Egyptian, Iraqi and Jordanian textbooks are written in Arabic and were translated into English. There are times when it can be difficult translating specific meanings and words and could alter the translation according to their understanding of the genre or nuances of the language. In cases where single words (e.g. adverbs or stimuli for word association) are translated without a contextual frame; it is extremely problematic to grasp the meaning of the source language and provide its equivalence in the target language. In effect the researchers had more than one translator look at the Arabic source language and check the translations made to English.

\section{RESULTS}

The following discussion develops how these textbooks present the Arab-Israeli conflict centering on issues common to each textbook.

\section{Textbook definitions and descriptions}

The way textbooks define terms or the language used in descriptions is important because this shapes students' views of historical episodes. In this study, Zionism is one of these key terms. Zionism is used in three of the five Arabic textbooks. The following two excerpts provide the authors' definitions of the term.

\footnotetext{
${ }^{3}$ The American Textbook Council provides information based on major adoptions in Texas (2003), California (2005) as well as in Indiana, North Carolina, Florida and New York. See http://www.historytextbooks.org/adoptions.htm for specifics regarding adopted textbooks.
} 
"Zionism is a racist, aggressive and colonial movement aimed at gathering the Jews of all nationalities around the world in Palestine through the migration and displacement of the Arab people. Zionism also aims to impede Arab's unity and to erase their cultural identity for the purpose of achieving a Jewish state stretching from the Euphrates to the Nile" (Mothfer and Mohamad, 2009).

"Zionism is a racist political movement founded by the Jews of Russia in the mid-eighteenth century, aimed to raise Jewish Diaspora and establishing a homeland in Palestine ... The Zionist thought is characterized as: Racial, Settlement and Diversionary thought ... Zionism emerged when the Jews rewrote the Torah and built an imaginary history and rights in establishing a homeland in land of Palestine ... Jews were invited to the reunion and return to the Promised Land and colonize Palestine and establish the State Israel" (Al Abedlaat et al., 2009, p. 125).

These definitions put forth an understanding of Israel and its position in the Middle East. The American textbooks describe Zionism as seeking a Jewish homeland while Arab textbooks utilize terms such as 'racist','aggressive' and "a colonial movement that displaces Arab people and prevents Arab unity". The Iraqi textbook uses the term 'Zionist Entity' when mentioning Israel and describes Israel as the "occupied lands" (Mothfer et al., 2009, p. 69). This illustrates the rejection of Israel as a national entity. Only one American textbook uses Zionism and the authors define the term as follows "The UN plan was a victory for Zionism - the movement seeking a Jewish homeland in Palestine" (Boyer and Stuckey, 2005, p. 564).

The term 'Israeli religious fundamentalists' (Lapsansky-Werner et al., 2008, p. 607) is use to describe Yitzak Rabin's assassin. Other terms include 'Jewish extremist' and 'Palestinian extremist' linked to suicide bombings (Cayton et al., 2007). What do these terms mean? What are the beliefs of Israeli religious fundamentalists or Palestinian extremists? What beliefs led to the assassination or suicide bombings? By not providing a definition, students are left to rely on their own understandings, media portrayals and most likely stereotypes that shape their understandings of the Arab-Israeli conflict.

\section{Specific Arab-Israeli conflicts}

Textbooks cannot cover all the Arab-Israeli conflicts but there are significant years addressed. The important dates are: 1947-1948, and 1973. Although Arab textbooks include the 1967 war, American textbooks are silent so that event was not examined.

\section{The 1948 war: Causes and results}

\section{Arab textbooks}

The overall presentation of the 1948 war in Arabic textbooks is that the British could not resolve the Palestinian case so they withdrew their troops, leaving affairs in the hands of the Zionists and the situation was subsequently turned over to the United Nations. The UN announced the partition resolution that divided Palestine into two states: Arab and Jewish with Jerusalem remaining under the guardianship of the United Nations. The Arabs rejected the partition while the Jews welcomed the decision (Al Tarwneh et al., 2009b). After the British withdrawal, "Jews declared the state of Israel which was recognized by the United States and the Soviet Union and other countries in the world" (Egypt textbook p. 340). The following excerpts illustrate this coverage:

"Prior to the British withdrawal, the Arab governments decided to send their armies to stop the partition of Palestine and prevent the establishment of the occupying Zionist entity" (Mothfer and Mohamad, 2009, p. 70).

"When the British armies withdrew, the Zionists declared the establishment of the Zionism entity ... However Britain refused and allowed the Zionists to take control of places previously under their control according to the partition resolution... The Zionists used oppressive and destructive tactics against Palestinians in collaboration with the British ... The Arab armies entered into Palestine and the Iraqi army was in the forefront ... The Zionist forces were six times the number of the Iraqi army ... Even after Tel Aviv became the capital of the Zionist entity, the Iraqi forces continued to fight" (Iraqi Textbook, p. 40). 
The excerpts illustrate the knowledge, perspectives and language used to describe this aspect of history and what students have the opportunity to learn from their textbooks.

War results The results of the war are described in a similar manner throughout the Arab textbooks. The following excerpts illustrate the knowledge and perspective presented to students.

"Arabic governments have bowed to the foreign pressure and agreed to the truce that led to the rescue and survival of the Zionist entity in Palestine" (Mothfer and Mohamad, 2009, p. 70).

"Arab armies achieved clear victories but the UN resolution to halt the fighting (that was agreed upon and committed to by the Arabs) transformed military situations in Israel's favor" (Al Tarwneh et al., 2009a; Al Tarwneh et al., 2009b, p. 45).

"Israel not only captured the lands allocated by the United Nations to the Jews under the partition resolution, but also occupied the north and west of Palestine and reached the Eilat port ... Arab states were forced to sign a truce agreement ... about a million refugees were displaced ... Arab states refused to recognize Israel” (Al Wisam in History, 2009, p. 340).

These excerpts provide a clear image of the perspectives put forth by Arab textbooks regarding the war, results and Israel's role in the conflict.

American textbooks All US textbooks address the UN partition and Israeli Declaration of Independence to various degrees. The treatment usually follows the path of Palestine being created by the UN partition, UN forces withdrew, Jewish leaders proclaimed the State of Israel and Arab countries reacted violently. The following excerpt is the most comprehensive and provides an example of how this event is typically portrayed by American textbooks:

"In 1947 Britain turned the issue over to the United Nations. The UN came up with a plan to divide Palestine into two states - one for Jews, and the other for Arabs - but the Arabs rejected the proposal ... The Arab states, however, reacted violently. They refused to recognize Israel and organized military forces to reclaim the state for Palestine ....Although vastly outnumbered, Israeli forces under Ben-Gurion overall command captured and held much of Palestine. Israeli soldiers used an arsenal bought in part with millions of dollars that poured in from the American Jewish community" (Boyer and Stuckey, 2005, p. 565).

Boyer and Stuckey continue that the UN mediator Count Folke Bernadottte who negotiated a "shaky" cease-fire and was assassinated by Israeli extremists. Then in 1949 Ralph Bunche persuaded both sides to accept an armistice. Bunche becomes the first African American to receive the Nobel Peace prize. The text tells that Israel gained more territory than the earlier UN partition and that Jerusalem was divided into Arab and Israeli zones.

There are two other issues raised within these textbooks that are omitted from the Arab texts. Cayton et al. (2007) point out that the US supported Israel while Russia backed the Arab nations. Furthermore, the US attempted to prevent oil-rich Arab nations from coming under the influence of the Soviet Union.

\section{October 1973}

The 1973 Egyptian and Syrian surprise attack on Israel is a major event in the tumultuous history of these nations. In 1967, Egypt and Syria developed an attack on Israel on the Jewish holiday of Yom Kippur.

"Egypt has rebuilt itself again and decided to liberate Sinai from the Zionists and the decided that the Suez Canal should restart navigation and work. On the 6th of October, the Egyptian forces crossed the Suez Canal and destroyed the Bar Lev line which was built by the Zionists on the bank of the eastern canal to prevent the Egyptian forces from crossing ... Iraq has provided effective support for Egypt in this war, though was not informed of the zero hour" (Mothfer and Mohamad, 2009, p. 72).

The impression created by these textbooks is "the Arabic countries took the initiative" (Al Tarwneh et al., 2009a; Al Tarwneh et al., 2009b, p. 45) because Egypt and Syria wanted to get their occupied lands back and planned an attack that would be carried out on October 6, 1973. Egyptian and Syrian 
forces attacked and defeated Israel and freed Sinai. Additional information mentioned includes the Arab's use of oil as a weapon by reducing oil exportation to the United States.

American textbooks When addressing October 1973, the American textbooks center on two specific elements. Firstly, there are four textbooks that center on the discussion of the oil embargo by OPEC nations. For example, one textbook provides the following excerpt under the heading Oil Crisis:

"In 1973, Israel and the Arab nations of Egypt and Syria went to war. The United States backed its ally Israel. In response, the Arab members of Organization of Petroleum Exporting Countries (OPEC) imposed an embargo, or a ban, on the shipping of oil to the United States. OPEC, a group of nations that cooperate to set oil price and production levels, also quadrupled its prices. The cost of foreign oil skyrocketed" (Cayton et al., 2007, p. 828).

These textbooks provide little details of the war but rather limit the discussion to the US support of Israel and the Arab use of oil as a political and economic weapon.

Two textbooks move beyond the economic implications for the US and provide some details of the war. The following excerpt from a US textbook describes the event:

"In 1973 Egypt and Syria invaded Israel in an attempt to gain back land last in 6-day war six years earlier. Attack on Jewish holiday Yom Kippur, surprised Israelis. Israel launched a counter attack and threatened Cairo. Soviets threatened to send in troops, US forces went on high alert. Major military confrontation seemed possible. Within days the superpowers persuaded the Arabs and Israelis to accept a cease-fire. Détente had survived but peace in the Middle East remained in doubt" (Boyer and Stuckey, 2005, p. 746).

These two textbooks raise the issue of Soviet support of Egypt and Kissinger is drawn into the discussion: "Nixon and Kissinger saw this conflict as an opportunity for the United States to assume a peacemaking role in the Middle East and thus gain an edge over the Soviet Union in the region" (Nash, 2004, p. 819). The textbook continues by describing how Kissinger tried to determine the war's outcome by withholding and granting supplies to Israel and after the embargo, Kissinger had an urgent need to establish better relations with the Arab countries, "even at the expense of Israel" (Nash, 2004, p. 819).

The textbook goes on describing Kissinger shuttling back and forth between the countries in an attempt to broker lasting peace. In September 1975, Egypt and Israel signed a peace agreement: Egypt officially recognized Israel and Israel withdrew from the Sinai Peninsula, the first ever withdrawal from occupied lands. Egypt then abandons the Soviet Union in favor of the United States but "by shutting the Soviets and the Palestinians out of the Middle East negotiations ... encouraged the Soviet Union to arm radical Arab factions such as the Palestinian Liberation Organization" (Nash, 2004, p. 819).

\section{UN resolutions}

The importance of addressing the number United Nations resolutions, what amount of space should be provided and the depth of the coverage can be debated. The Arab textbooks provide students with information regarding several UN resolutions:

"In 1973, the United Nations issued the Resolution 338 that called for all the parties (Israel and Palestine) to go back to the 1967 borders" (Al Tarwneh et al., 2009a; Al Tarwneh et al., 2009b, p. 50).

"In 1967, the United Nation issued the 242 resolution, which called for a cease fire, a withdrawal of Israeli forces from the territories occupied in 1967 and the guarantee of the peace of the countries of the region while assuring freedom of shipping in international waterways and resolution of the refugee problem" (Al Wisam in History, 2009, 344).

The following excerpt illustrates how American textbooks address UN resolutions.

"The UN came up with a plan to divide Palestine into two states one for Jews and the other for Arabs-but Arabs rejected the proposal" (Boyer and Stuckey, 2005). 
Although Arab textbooks raise several UN resolutions, American textbooks limit the role of the United Nation to Resolution 181 that divided Palestine and partition the land into a Jewish and Arab section.

\section{Israel: Threat or victim}

Arab textbooks suggest several reasons why Israel is a threat to the Arab world. This includes Israel's expansionist policy that forces Arab countries to remain on standby in case of Israeli aggression. This impacts Arab countries budgets by forcing Arabs to funnel finances into a military budget instead of investing in other development projects. Secondly, Israel plays a role in the obstruction of Arab unity and prevents communication between Arab States in Asia and Africa. Finally, Israeli nuclear threat is considered the most serious danger for the Arab nations.

Unlike the Arab textbooks, US textbooks position Israel more as a victim. Several textbooks clearly state that the US supports Israel and provide explanations of US support because of Palestinian attacks and the Arab world's rejection of Israel as a national entity. American textbooks seem to present the US not so much as an ally of Israel but rather as a country seeking peace in the region. Most of the coverage in these textbooks is spent on the US attempts at various summits in the development of peace agreements between the Arab nations and Israel.

The Egyptian textbook is quite clear about the US-Israel relationship. The following textbook excerpt illustrates the portrayal US-Israel relations:

"The United States was highly biased to Zionism because the Zionists helped in breaking the Nazi regime in Germany. Also Zionists served United States' interests in the Middle East, which has become of a great significance because the oil companies operating in the Gulf proved that the area sits on a lake of oil. Thus who controls the Middle East dominates the world" (Al Wisam in History, 2009, p. 337).

Although this excerpt is short, it raises some fundamental issues regarding US foreign policy in the Middle East.

\section{The peace process}

Historically, there have been many attempts to develop a long-lasting peace between the Arab Nations and Israel. One Arab textbook addresses the peace process with the following statement:

"In 1993, secret negotiations took place between Israel and the Palestine Liberation Organization in Oslo, Norway. A peace treaty was signed between the Palestinian President Yasser Arafat and Israeli Prime Minister Yitzhak Rabin in the presence of US President Bill Clinton and there was mutual recognition between Israel and the PLO" (Al Tarwneh et al., 2009a; Al Tarwneh et al., 2009b, p. 53).

Egyptian authors inform students that in 1978 the President of the United States, Jimmy Carter, the Egyptian president, Anwar al Sadat and Menachem Begin, the Prime Minister of Israel held a meeting in Camp David that ended with the creation of a peace framework. The framework included Israel's full withdrawal from Sinai; the normalization of relations between Egypt and Israel; provision of legitimate rights for the Palestinian people by involving representatives from Jordan and Palestine in determining the future of the West Bank and Gaza Strip; and an end to Israeli military rule and the establishment of full Palestinian self-government (Al Wisam in History, 2009, p. 356).

American textbooks The majority of space devoted to the Arab-Israeli conflict also centers on the US role in promoting peace in the region. Five textbooks provide pictures of Jimmy Carter, Anwar al Sadat and Menachem Begin either shaking hands or signing a peace agreement. One textbook provides a picture of Clinton with Ehyd Barak and Yasir Arafat at Camp David in 2000. Four of the American textbooks provide a limited discussion that tells readers that the leaders met, discussed the issues, left with a framework for peace and that several of the leaders won the Nobel Prize for their efforts.

Two textbooks provide more details for readers. The most comprehensive account discusses the Camp David Accords and states that the result was a framework for peace:

"Israel would withdraw from the Sinai Peninsula, which it had occupied since 1967, Egypt, in return, became the first Arab country to recognize Israel's existence as a nation. The Camp David Accords, of course, did not solve all the problems in the Middle East. Among the remaining problems were issues concerning the Palestinians. Many had fled 
their homes when Arab nations declared war on Israel immediately after the country was established in 1948" (Cayton et al., 2007, p. 855).

One textbook addresses Clinton's 1993 attempt for peace when he led secret negotiations in Oslo, Norway between Arafat and Barak and Clinton's 2000 meetings at Camp David.

"The resulting declaration of principles promised Palestinian self-rule in Jericho and the Gaza strip, as well as security for the Israelis. The declaration did not end Israeli settlement of the West Bank, a major issue that led to chronic violence, nor did it in any way placate extremists on both sides who had no interest in compromising. In 2000, Clinton invited Palestinian leader Yasir Arafat and Israeli Prime Minister Ehud Barak to Camp David to work on a peace agreement. They came close to signing one, but in the end could not agree. Back in Israel Barak was ousted by Ariel Sharon, a "hawk" who opposed any concessions to the Palestinians. At the same time, violence in the region escalated. Palestinian suicide bombings increased, and with them so did crackdowns by the Israeli military" (Boorstin and Kelley, 2007, p. 782).

These two historical accounts move beyond simplification of the peace process and begin to give some of the important details. Offering specific results of the negotiations, informing about the problems that exist and using the term "hawk" allows students to raise possible questions concerning the peace process.

\section{DISCUSSION}

The purpose of this research is not to evaluate and determine the 'best' textbook or what authors provide extensive coverage of the Arab-Israeli Conflict. Rather our goal is to point out the strengths and limitations of the content covered, address important information omitted and provide recommendations to improve the teaching of the conflict in a manner that students are exposed to a more comprehensive perspective.

The findings indicate that most textbooks knowledge is often oversimplified, important information is omitted and knowledge is present in a fact-stating manner with little room for discussion or question. It is clear that the politics of each nation shapes the portrayal of the Arab-Israeli conflict. For instance, Arab textbooks infer that the creation of the State of Israel by the United Nations was a non-legitimate act of the international community while US textbooks remain silent on the creation of the Israeli state.

Based on these findings, it is important that readers should not judge the content and perspective located in Arab or American textbooks without considering the politics of textbooks. Historical truths are socially constructed and are a result of complex power and ideological struggles. Apple and Christian-Smith (1991) argue that it is important to consider that 'official knowledge' usually centers on what is included and excluded in textbooks. However, textbooks suggest legitimate ways of looking at knowledge and signify more profound political, economic, and cultural relationships and histories. Hence, we see the Arab textbooks using the Zionist enemy because of their history and experiences within the Arab-Israeli conflict while the American textbooks unquestionably legitimize the development of Israel because of common interests.

Our concern is that specific knowledge is never made available for consideration. In what follows, we discuss what we see as the key textbook omissions, pointing out how missing information shapes student understanding of the Arab-Israeli conflict. We certainly understand that textbooks cannot include all the information about a particular topic but they can improve portrayals of historical events by adding a few sentences or raising important questions.

\section{United nation resolutions and US vetoes}

Although it is debatable as to the importance of listing and detailing the specific UN resolutions, there are aspects of the resolutions that should be developed in order for students to gain a clearer understanding of not only the Arab-Israeli conflict but also the United Nations role and both the Israeli and Arab response to various resolutions. UN Resolution 194 never appears in these textbooks. The main issue found in Article 11 of Resolution 194 stipulated that:

"the refugees wishing to return to their homes and live at peace with their neighbors should be permitted to do so at the earliest practicable date, and that compensation should be paid for the property of those choosing not to return and for loss of or 
damage to property which, under principles of international law or in equity, should be made good by the Governments or authorities responsible" (United Nations Resolution 194, 1948).

Traditionally Israel contested this reading arguing that the resolution merely states that the refugees "should be permitted" to return to their homes at the "earliest practicable date" and this recommendation applies only to those "wishing to... live at peace with their neighbors" (Gannon, 2003). Of course the UN resolutions are non-binding but still it is necessary for students to understand the perspective being presented by the UN.

Probably the key point regarding UN resolutions is that the Israeli leadership continues to defy countless UN resolutions pertaining to its policies and military tactics of the past 35 years. Israel has been the subject of 138 resolutions and has over $50 \mathrm{UN}$ resolution violations pertaining to its policies and military tactics since 1967 (Ladah and Suleiman, 2002). Many of these resolutions call upon Israel to comply with basic principles of international law and others request Israel to comply with previous resolutions that Israel ignored and continues to ignore to this day. Israel has been targeted by at least 65 UN resolutions and the Palestinians have been targeted by none (Findley, 1995).

There are a variety of questions regarding the UN that are never raised within these textbooks. For example, does the United Nations have the authority and ability to enforce a solution against the wishes of the majority of the native population? Furthermore, none of the textbooks examined address who voted for, against or abstained from the voting on the decision to divide Palestine. The resolution was approved by the general assembly, 33 votes in favor, 13 votes against, with 10 abstentions. We believe it is important for students to see who supported the decision and who opposed. For example of the 13 opposed, Cuba, Greece and India were the only countries outside the Middle East. The United Kingdom abstained while both the Former Soviet Union and the US voted in favor of the decision. This information could easily be used by teachers to develop student's critical thinking skills by engaging in predication as to why countries voted they way they did.

Concerning veto power and the UN, Neff (1998) calculates that Washington used its veto 32 times to shield Israel from critical draft resolutions between 1972 and 1997.4 Since 1990, the US has cast more Security Council vetoes than any country, many of them favoring Israel, a longtime ally (Hastings, 2003).

\section{Palestinian refugees}

Palestinian refugees are persons whose normal place of residence was Palestine between June 1946 and May 1948, who lost both their homes and means of livelihood as a result of the 1948 Arab-Israeli conflict (United Nations Relief and Works Agency, 0000). Analysis of both the American and Arab textbooks uncovers a serious omission that hampers students from developing a complex understanding of the Arab-Israeli conflict. Beyond simple mentioning, not a single textbook provides a substantial discussion regarding the Palestinian refugees that is a fundamental concern in the Arab-Israeli conflict. For example, Al Tarwneh et al. (2009a); Al Tarwneh et al. (2009b) writes "Thousands of Palestinians were forced to leave their lands on the West Bank and Gaza strip." No further explanation is provided.

In June 1967 [East] Jerusalem was annexed to Israel that started the beginning of a process of settlement activity. These camps are located in various areas such as Jordan, Lebanon, the Syrian Arab Republic, the West Bank and Gaza Strip. The camps are placed on land leased by the host government meaning that the refugees do not own the land but have the right to use the land. The United Nations Relief and Works Agency (UNRWA) points out that the socio-economic conditions in the camps are generally poor with a high population density, cramped living conditions and inadequate basic infrastructure such as roads and sewers. UNRWA began operations in 1950 and responded to the needs of about 750,000 Palestinian refugees. Today, 4.7 million Palestinian refugees are eligible for UNRWA services. Even though the refugee problem has been at the heart of the peace negotiations ever since 1949, the hardships of the Palestinian refugees and personal struggles are omitted. No Israeli homes have been demolished by Palestinians, whereas 24,145 Palestinian homes have been demolished by Israel since 1967 (The Israeli Committee Against Home Demolitions, 2009). Furthermore, one can argue that the Gaza Strip is the largest concentration camp in the world. There

\footnotetext{
${ }^{4}$ A complete list of the vetoes was printed in Donald Neff, "Vetoes Cast by the United States to Shield Israel from Criticism by the U.N. Security Council," Washington Report on Middle East Affairs, March 1993.
} 
are 1.5 million Palestinians living in the Gaza Strip who suffer daily hardships. Snorre and Wilhelmson (2008) point out that malnutrition of children is on the rise, water supplies and drainage have ceased to function, food, fuel and medicine deliveries are made difficult or stopped altogether and children die for lack of healthcare. It is evident that Israel has not lived up to the requirements stipulated by the UN and that the Palestinians who had been evicted from their homes have not been allowed to return at the earliest possible opportunity (Snorre and Wilhelmson, 2008).

\section{Intifadas}

These textbooks fail to mention intifadas, an Arabic term that literally means 'shaking off' but is usually translated as uprising or resistance. The term is often used for a popular resistance to oppression or how the oppressed fight oppression. In the case of textbooks, intifada refers to historical events such as the First Intifada from 1987-1993, the Second Intifada from 2000 to 2005 to name just a few. Intifadas do not just 'happen' but are caused by a particular event. Textbooks should provide the complex causes for intifada in order to provide this narrative. These causes include; policies of occupation, those aimed at erasing Palestinian national identity, the demolishing of homes, death, checkpoints, poor working conditions and poor treatment of the workers, searches in vehicles and homes and the inability of the Palestinians to make any real economic, professional or personal advancement. Furthermore it should be pointed out that Palestinians have used mass nonviolent resistance for generations - as early as the long strike of 1936 and that "violence and nonviolence are mostly collective decisions that are shaped and driven by specific political and socio-economic conditions and contexts. Unfortunately, the violence of the occupier has a tremendous role in creating and manipulating these conditions" (Baroud, 2010, para. 17). The key is to present the unique experience of the Palestinian people and their genuine struggle for freedom. This knowledge allows students to see multiple narratives and offers opportunities to raise important questions centering on power, oppression and appropriate response.

\section{The US and the Middle East}

Another vital omission is the relationship between the US and Israel. In the American textbooks, the majority of space devoted to the Arab-Israeli conflict centers on the US role in promoting peace in the region. The impression created by these textbooks is one that the US appears as a 'neutral' body working hard toward developing peace in the Middle East. However, the concern of the US's lack of neutrality is omitted.

Absent from the discussion is the political, military and economic support provided to Israel by the US. Textbooks fail to inform readers that as a direct result of the October 1973 war, the US quadrupled its foreign aid to Israel, and replaced France as Israel's largest arms supplier (Palestine Facts, 2010). Furthermore, there is no discussion regarding the amount of financial aid given to Israel by the US. It is estimated that the cumulative total direct aid to Israel is nearly US\$114billion, meaning that Israel receives about US\$3billion in direct foreign assistance each year, which totals roughly one-fifth of the US's entire foreign aid budget (Washington Report on Middle East Affairs, 2006). This level of support dwarfs the amounts given to any other state making Israel the largest annual recipient of direct US economic and military assistance since 1976 and the largest total recipient since the second world war (Mearsheimer and Walt, 2007).

The US provided US $\$ 225$ million economic aid to the Palestinians and US\$75million for support of Palestinian police training in 2009. The US also provided just over US $\$ 61.5$ million emergency humanitarian aid through United States Agency for International Development (USAID), UNRWA, and the International Committee of the Red Cross, following Israel's assault on Gaza (Mearsheimer and Walt, 2007). The Israeli-Palestinian conflict is one of the world's major sources of instability and the US is directly connected to this conflict. Students cannot understand the complex situation unless the complete role of the US and its relationship with Israel is disclosed.

\section{CONCLUSION}

History textbooks are not written to examine but rather to instruct students about what they should know and not know about their country (FitzGerald, 1979). History textbooks are imperfect educational tools and should not be the final word. Because of this, we think that teachers must play an important role in addressing the limited and at times bias textbook content. Let us offer several suggestions for classroom teachers:

The value any textbook is decided by teachers who mediate the content to students. We suggest that a narrative-based approach to history instruction should be utilized when possible. This 
approach to history activates reflective thinking and provides the opportunity for students to take the "other's" view of history. More importantly, the use of narratives in teaching and learning history provide opportunities for students to understand the human features of history. However, students must be taught that narratives are also interpretations of history and they should be encouraged to question all narratives. Lee (1998) argues that students should be exposed to different versions of historical events but they must also be taught to account for the difference.

Here are several practical suggestions that will develop a narrative approach to teaching history. Loewen (1995) suggests that teachers challenge textbook doctrine and deal with textbooks in a more critical manner by putting five questions to work. These questions are the initial stage of uncovering others' narratives. Loewen's questions are as follows: 1) Why was a particular event written about?; 2) Whose viewpoint is presented, who's omitted and whose interests are served?; 3) Is the account believable?; 4) Is the account backed up by other sources? and 5) How is one supposed to feel about what has been presented? These questions provide opportunities for students to begin to grasp the meaning of a 'frame of reference', oppositional narratives and how these play a role in selecting and organizing the information that makes up their history textbooks. When teachers or textbooks provide opposing narratives and viewpoints, students benefit by gaining an understanding that conflicts are multidimensional and dynamic rather than one-dimensional and static (Arida, 2006). Possibly more importantly, students will learn how to recognize their own personal biases and the ideologies that directly influence their perceptions and understanding of historical events (Arida, 2006). This is vital, especially when dealing with the Arab-Israeli conflict because the perspectives that are legitimized by textbooks support the status quo, not promoting peace but fueling further conflict.

Secondly, teachers could provide accurate and comprehensive definitions for complex terms. For example, Arabic teachers should teach students to differentiate between Judaism as a religion and Zionism as a political movement. Teachers could help their students if they challenged stereotypes that often accompany various terms such as 'Palestinian extremism', by elaborating on these complicated terms and providing answers to Loewen's critical thinking questions to gain insight into the value-laden meanings of these terms and how these meanings are embedded in the various narratives.

Thirdly, teachers could begin to focus not only on the historical content but also on particular thinking skills that will prove useful for students beyond the classroom walls. Wiggins and McTighe (2005) provide six facets of understanding that if used in the classroom, can aid students in gaining comprehensive understandings of historical events and uncovering narratives. Table 1 illustrates these categories.

Table 1. Taken from Six Facets of Understanding by Wiggins and McTighe (2005). Understanding by Design. Alexandria, VA: Association for Supervision and Curriculum Development.

\begin{tabular}{|c|c|}
\hline Category & What it is? \\
\hline Explain & $\begin{array}{l}\text { Students possess the knowledge to be able to developed } \\
\text { complicated explanations of the Arab-Israeli conflict including the } \\
\text { history and why the current situation exists. }\end{array}$ \\
\hline Interpret & $\begin{array}{l}\text { To give meaning by providing interpretations, narratives and } \\
\text { translations. This requires the student to be able make the subject } \\
\text { of study personal or accessible through images, anecdotes, } \\
\text { analogies, and models. }\end{array}$ \\
\hline Apply & $\begin{array}{l}\text { Students are able to use knowledge and apply it to new situations } \\
\text { and diverse contexts. }\end{array}$ \\
\hline Perspective & $\begin{array}{l}\text { Students should have the ability to see and hear differing points of } \\
\text { view through critical eyes that allow them to understand the 'big } \\
\text { picture'. Teachers and textbooks need to present opposing } \\
\text { viewpoints (Israeli, Palestinian, American, government and citizen } \\
\text { perspectives, etc.) in order to develop complex understandings. }\end{array}$ \\
\hline Empathy & $\begin{array}{l}\text { Students need to find value in what others narratives and } \\
\text { experience and come to sensitively understand the different lives } \\
\text { and experiences of others. Students need to understand the lives of } \\
\text { Palestinians and Israelis and the related struggles and issues of } \\
\text { concern. }\end{array}$ \\
\hline Self-Knowledge & $\begin{array}{l}\text { Students are able to critically reflect and uncover their personal } \\
\text { narratives, prejudices and habits of the mind that both shape and } \\
\text { impede their understandings. They are also able to identify their } \\
\text { limitations and how knowing just one perspective hampers } \\
\text { understanding. }\end{array}$ \\
\hline
\end{tabular}


Regarding the Arab-Israeli conflict, it would be particularly beneficial for students to apply the categories of perspective, empathy and self-knowledge to the conflict in order to increase their understanding of how their individual biases shape how they view the conflict and how this limits their understandings.

Finally, the teacher needs access to various readings and/or textbooks that can provide a more balanced perspective of the Arab-Israeli conflict and more importantly, textbooks need to provide students with not only their own narrative but also the narrative of others. For example, Adwan et al. (2002) provides a dual-narrative approach with a resource titled Learning Each Other's Historical Narrative: Palestinians and Israelis that attempts move beyond traditional textbooks and provides both teachers and pupils the opportunity to learn the other's narratives. The book is designed so that on each page, in between the Palestinian and Israeli narratives, space is provided for students to write their reflections about not only their own perspective and understandings of the conflict but also the oppositional viewpoints.

\section{References}

Adwan S, Bar-On D, Musallam A and Naveh E. (2002). Learning each other's historical narrative: Palestinians and Israelis.

Al Abedlaat M, Badawi F, Badran J, Ismail S, Ahmad H and Azabi I. (2009). The history of the Arabs and the modern world. Amman, Jordan: The Ministry of Education.

Al Tarwneh A, Al Kareem Ahmad A, Al Abedlaat M, Ismail S and Al Tarawneh M. (2009a). The modern and contemporary history of Arabs Part 1 Grade 10. Amman, Jordan: The Ministry of Education.

Al Tarwneh A, Al Abedlaat M, Ismail S and Al Tarawneh M. (2009b). The modern and contemporary history of Arabs Part 2 Grade 10. Amman, Jordan: The Ministry of Education.

Al Wisam in History. Islamic Civilization and Modern Arab History. Dar Gareeb Publishers, Cairo, Eqypt. 2009.

American Textbook Council. (2003). Islam and the textbooks: A report of the american textbook council. Middle East Quarterly Summer. 69-78. http://www.meforum.org/559/islam-and-the-textbooks

Anyon J. (1979). Ideology and United States history textbooks. Harvard Educational Review. 49:3, 361-386.

Apple MW and Christian-Smith LK. The politics of the textbook. Apple MW and Christian-Smith LK (Eds), The Politics of the Textbook. 1991; Routledge, New York. 1-21.

Arida H. (2006). Teaching the Middle East: The perspectives method. Teaching History: A Journal of Methods. 31:2, 74.

Bard M. Rewriting History in Textbooks. 1993; http://www.jewishvirtuallibrary.org/pub/texts.html

. Barlow E (Ed.), Evaluation of Secondary-Level Textbooks for Coverage of the Middle East and North Africa. Third Edition, 1994; Middle East Studies Association/Middle East Outreach Council, Ann Arbor, MI/Tuscon, AZ. .

Bar-Tal D. (2001). The Arab Image in Hebrew School Textbooks: How the Arabs were represented in Hebrew textbooks in Jewish and Israeli schools over one hundred years. Palestine-Israel Journal. 8:2, http://www.pij.org/details.php?id=884

Baroud R. (2010). Teaching the oppressed how to fight oppression, October $19^{\text {th }}$ Retrieved from http://arabnews.com/opinion/columns/article164908.ece?comments=all.

Boorstin D and Kelley B. A History of the United States. Pearson/Prentice Hall, Boston, MA. 2007.

Boyer P and Stuckey S. The American Nation. Holt, Rinehart, Austin, TX. 2005.

Cayton A, Perry E, Reed L and Winkler A. America: Pathways to the Present. Pearson/Prentice Hall, Boston, MA. 2007.

Cherryholmes CH, Heilman EE and Segal A. Social Studies-the Next Generation: Re-searching in the Postmodern Counterpoints: Studies in the Postmodern Theory of Education. Peter Lang Publishing, New York. 2005.

De Castell Luke, A and Luke C. Editorial introduction: Language authority and criticism. De Castell S, Luke A and Luke C (Eds), Language Authority and Criticism: Readings on the School Textbook. 1989; The Falmer Press, Philadelphia. vii-xi.

Eisner EW. The Educational Imagination: On Design and Evaluation of School Programs. Third Edition, Macmillan, New York. 1994.

Findley P. Deliberate Deceptions. American Educational Trust, Washington, DC. 1995.

FitzGerald F. America Revised. Random House, New York. 1979.

Gannon S. (2003). Who's afraid of resolution 194? Israel Insider, August. http://web.israelinsider.com/Views/2654.htm.

Giroux HA. Teachers as Intellectuals: Toward a Critical Pedagogy of Learning. Bergin and Garvey Publishers Inc., Massachusetts. 1988

Hastings D. (2003). U.S. uses UN veto power more than others. Information Clearinghouse. http://www.informationclearinghouse.info/article2016.htm.

Hein L and Selden M. The lessons of war, global power, and social change. Hein L and Selden M (Eds), Censoring History: Citizenship and Memory in Japan, Germany, and the United States. 2000; M.E. Sharpe, Armonk, NY. 3-4.

Ladah MS and Suleiman IA. (2002). Mr. Bush, what about Israel's defiance of UN resolutions? An open letter to George W. Bush. http://www.mediamonitors.net/michaelsladah\&suleimaniajlouni1.html.

Lapsansky-Werner E, Levy P, Roberts R and Taylor A. A United States History. Pearson/Prentice Hall, Boston, MA. 2008.

Lee P. (1998). Making sense of historical accounts. Canadian Social Studies. 32:3, 52-54.

Loewen JW. Lies My Teacher Told Me: Everything Your American History Textbook Got Wrong. The New Press, New York. 1995.

McLaren Peter. Life in Schools: An Introduction To Critical Pedagogy in The Foundations of Education. Third Edition, White Plains, Longman, an imprint off Addison Wesley Longman, NY. 1998.

Mearsheimer JJ and Walt SM. (2007). The Israel lobby and U.S. foreign policy [Kindle Version]. Retrieved from Amazon.com. 
Mothfer M and Mohamad KI. The Modern and Contemporary History of Arab Countries. Ed. 15, The Ministry of Education, Baghdad, Iraq. 2009.

Moughrabi F. (2001). The politics of Palestinian textbooks. The Journal of Palestine Studies. 31:1, 5-19.

Nash G. American Odyssey. McGraw-Hill/Glencoe, New York. 2004.

Neff D. (1998). U.S. Vetoes of U.N. Resolutions on Behalf of Israel.

http://www.ifamericansknew.org/us_ints/p-neff-veto.html.

Palestine Facts. (2010). http://www.palestinefacts.org/pf_1991to_now_israel_us_support.php.

Romanowski MH. (2009). Excluding Ethical Issues From U.S. History Textbooks: 911 and the War on Terror. American Secondary Education. 37:2,

Snorre L and Wilhelmson L. (2008). Revoking Israel's UN Membership. Palestine Chronicle. http://www.palestinechronicle.com/view_article_details.php?id=14445.

The Israeli Committee Against Home Demolitions. (2009). Statistics on house demolitions (1967-2009).

United Nations Relief and Works Agency. http://www.unrwa.org/etemplate.php?id=86.

United Nations Resolution 194. (1948).

http://domino.un.org/unispal.nsf/0/c758572b78d1cd0085256bcf0077e51a?OpenDocument.

Washington Report on Middle East Affairs. http://wrmea.org/component/content/article/245-2008-november/ 3845-congress-watch-a-conservative-estimate- of-total-direct-us-aid-to-israel-almost-114-billion.html.

Weber RP. Basic Content Analysis. 2nd ed., Sage, Newbury Park, CA. 1990

Wiggins $\mathrm{G}$ and McTighe J. Understanding by Design. Association for Supervision and Curriculum Development, Alexandria, VA. 2005.

Wingfield M and Karaman B. (1995). Arab Stereotypes and American Educators. http://www.adc.org/education/arab-stereotypes-and-american-educators/.

\section{TEXTBOOKS INCLUDED IN THIS STUDY}

Egyptian textbook

1. Al Wisam in History: Islamic Civilization and Modern Arab History.

Iraqi textbook

1. The Modern and Contemporary History of Arab Countries.

Jordanian textbooks

1. The History of the Arabs and the Modern World.

2. The Modern and Contemporary History of the Arabs. Part 1 Grade 10

3. The Modern and Contemporary History of the Arabs. Part 2 Grade 10

United States textbooks

1. American Anthem

2. A History of the United States

3. America: Pathways To The Present

4. The Americans

5. American Odyssey

6. The American Nation
Cairo, Eqypt: Dar Gareeb

2009

Publishers

Iraqi Ministry of Education

2009

Jordanian Ministry of

2009

Education

Jordanian Ministry of

2009

Education

Jordanian Ministry of

2009

Harcourt/Holt

Pearson/Prentice Hall

Pearson/Prentice Hall

Houghton Mifflin/McDougal

McGraw-Hill/Glencoe

Holt, Rinehart and Winston
2006

2007

2007

2007

2004

2005
ATC Listed

ATC Listed

ATC Listed

ATC Listed

ATC Listed ATC Listed 